\title{
Article
}

\section{Ketone Hydrogenation with Iridium Complexes with "non N-H" Ligands: The Key Role of the Strong Base}

Hayes, Joseph M., Deydier, Eric, Ujaque, Gregori, Lledós, Agustí, Malacea-Kabbara, Raluca, Manoury, Eric, Vincendeau, Sandrine and Poli, Rinaldo

Available at https://clok.uclan.ac.uk/13290/

Hayes, Joseph M. orcid iconORCID: 0000-0002-7745-9616, Deydier, Eric, Ujaque, Gregori, Lledós, Agustí, Malacea-Kabbara, Raluca, Manoury, Eric, Vincendeau, Sandrine and Poli, Rinaldo (2015) Ketone Hydrogenation with Iridium Complexes with "non N-H" Ligands: The Key Role of the Strong Base. ACS Catalysis, 5 (7). pp. 4368-4376. ISSN 2155-5435

It is advisable to refer to the publisher's version if you intend to cite from the work. http://dx.doi.org/10.1021/acscatal.5b00613

For more information about UCLan's research in this area go to

http://www.uclan.ac.uk/researchgroups/ and search for <name of research Group>.

For information about Research generally at UCLan please go to http://www.uclan.ac.uk/research/

All outputs in CLoK are protected by Intellectual Property Rights law, including Copyright law. Copyright, IPR and Moral Rights for the works on this site are retained by the individual authors and/or other copyright owners. Terms and conditions for use of this material are defined in the policies page. 
Joseph M. Hayes, Eric Deydier, Gregori Ujaque, Agustí Lledós, Raluca Malacea, Eric Manoury, Sandrine Vincendeau, Rinaldo Poli. Ketone Hydrogenation with Iridium Complexes with "non $N$-H" Ligands: the Key Role of the Strong Base. ACS Catalysis, 61, 231-242, 2015. DOI: $10.1021 /$ acscatal.5b00613

\section{Ketone Hydrogenation with Iridium Complexes with}

\section{"non N-H" Ligands: the Key Role of the Strong}

\section{Base.}

Joseph M. Hayes ${ }^{a} \dagger$, Eric Deydier ${ }^{b}$, Gregori Ujaque $^{a}$, Agusti Lledós $^{a *}{ }^{*}$ Raluca Malacea ${ }^{b} \neq$, Eric Manoury $^{b}$, Sandrine Vincendeau ${ }^{b}$ and Rinaldo Poli ${ }^{b, c *}$

${ }^{a}$ Departament de Química, Universitat Autònoma de Barcelona, 08193 Bellaterra (Barcelona) Spain.

${ }^{b}$ Laboratoire de Chimie de Coordination, UPR CNRS 8241 liée par convention à l'Université Paul Sabatier et à l'Institut National Polytechnique de Toulouse, 205 Route de Narbonne, 31077 Toulouse Cedex 4, France.

'Institut Universitaire de France, 103, bd Saint-Michel, 75005 Paris, France.

KEYWORDS Catalyzed ketone hydrogenation. Catalyzed transfer hydrogenation. Iridium. Bifunctional ligands. Asymmetric catalysis. Effect of strong base. 


\section{ABSTRACT}

Ferrocenyl phosphine thioether ligands (PS), not containing deprotonatable functions, efficiently support the iridium catalyzed ketone hydrogenation in combination with a strong base co-catalyst. Use of an internal base $\left([\operatorname{Ir}(\mathrm{OMe})(\mathrm{COD})]_{2}\right.$ in place of $\left.[\operatorname{IrCl}(\mathrm{COD})]_{2}\right)$ is not sufficient to insure activity and a strong base is still necessary, suggesting that the active catalyst is an anionic hydride complex. Computational investigations that include solvent effects demonstrate the thermodynamically accessible generation of the tetrahydrido complex $\left[\mathrm{IrH}_{4}(\mathrm{PS})\right]^{-}$and suggest an operating cycle via a $\left[\mathrm{Na}^{+}(\mathrm{MeOH})_{3} \cdots \mathrm{Ir}^{-} \mathrm{H}_{4}(\mathrm{PS})\right]$ contact ion pair with an energy span of 18.2 $\mathrm{kcal} / \mathrm{mol}$. The cycle involves an outer sphere stepwise $\mathrm{H}^{-} / \mathrm{H}^{+}$transfer, the proton originating from $\mathrm{H}_{2}$ after coordination and heterolytic activation. The base plays the dual role of generating the anionic complex and providing the Lewis acid co-catalyst for ketone activation. The best cycle for the neutral system, on the other hand, requires an energy span of $26.3 \mathrm{kcal} / \mathrm{mol}$. This work highlights, for the first time, the possibility of outer sphere hydrogenation in the presence of non deprotonatable ligands and the role of the strong base in the activation of catalytic systems with such type of ligands. 


\section{Introduction}

The reduction of carbonyl compounds and particularly the enantioselective reduction of prochiral ketones, leading to optically pure secondary alcohols, has been the topic of a considerable number of studies because of its significance for the manufacture of pharmaceuticals and advanced materials. ${ }^{1-4}$ Remarkable efforts have been devoted to the development of this method by using organometallic complexes as catalysts. The majority of the work carried out in this area has employed ruthenium-based pre-catalysts in combination with a variety of phosphine and amine ligands. ${ }^{5-10}$ Of these, the family of $\left[\mathrm{RuCl}_{2}\right.$ (diphosphine)(diamine)] molecules developed by Noyori, Ikariya, Ohkuma and coworkers stands out. ${ }^{11-14}$ Efficient enantioselective catalysts based on rhodium, ${ }^{15-17}$ iridium, ${ }^{18-26}$ and iron $^{27-36}$ have also been reported in the literature. Interest in iridium as a catalytic metal is sparked by the observation that it outperforms rhodium for the ionic hydrogenation of particularly difficult substrates such as imines and industrial processes based on Ir-catalyzed ketone hydrogenation have been implemented. ${ }^{37-40}$

Contrary to olefins, unsaturated oxygenated substrates may be hydrogenated by the outer sphere mechanism, ${ }^{41,42}$ without substrate coordination. These processes are also characterized by the need of a strong base co-catalyst in order to function. In the generally accepted view, a proton from a metal coordinated $\mathrm{XH}$ function (typically an amine) is transferred to the $\mathrm{O}$ atom and a hydride is

transferred to the $\mathrm{C}$ atom (Scheme $1, \mathbf{I} \rightarrow \mathbf{I I}) .{ }^{43}$ The invoked role of the base in Noyori's systems is to allow the catalyst to remain in a more active neutral form (cycle B), whereas only the slower cycle A via the protonated form III would occur without base. ${ }^{44}$ Indeed, certain isolated amido systems (e.g. complexes of type II) are active catalysts in the absence of added base. ${ }^{43}$ Computational explorations of this mechanism, mostly carried out in the gas phase, have analyzed 
the neutral cycle (B) but have not addressed the role of the base, ${ }^{43,45-66}$ except for occasionally verifying that the base-promoted $\mathrm{HCl}$ removal from a chloride complex pre-catalyst is exothermic. ${ }^{67}$ Only one recent study has addressed the role of the base, using a solvent model, for the further deprotonation of the NH donor function in the neutral hydride complex with generation of a more active anionic complex. ${ }^{68}$

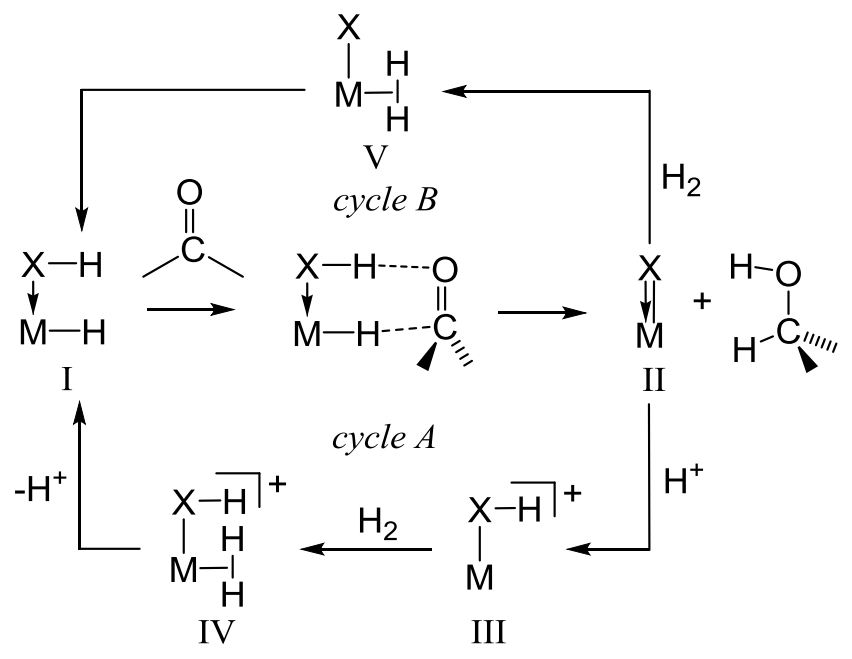

Scheme 1. "Classical" outer sphere mechanism for the hydrogenation of ketones.

There are, however, efficient systems that do not contain active protons and yet a strong base is crucial. For instance, the iridium complexes $\left[\operatorname{Ir}(\mathrm{COD})\left(\mathbf{1}^{\mathbf{R}}\right) \mathrm{Cl}\right]\left(\mathbf{2}^{\mathbf{R}}\right.$ where $\mathbf{1}^{\mathbf{R}}=\{\mathrm{CpFe}[1,2-$ $\left.\mathrm{C}_{5} \mathrm{H}_{3}\left(\mathrm{PPh}_{2}\right)\left(\mathrm{CH}_{2} \mathrm{SR}\right)\right\}$, Scheme 2$)^{69}$ are good pre-catalysts for aromatic ketone hydrogenation in alcohol solvents, ${ }^{70}$ although only in the presence of a strong base such as MeONa or $t \mathrm{BuOK}$. No significant activity was observed in the absence of $\mathrm{H}_{2}$ or when a weaker base such as $\mathrm{NEt}_{3}$ was used. This behavior is shared by many other catalysts that are devoid of active protons, whether they are used in hydrogenation ${ }^{20}$ or transfer hydrogenation. ${ }^{71-80}$ The common view is that the base is needed to eliminate the acidity generated during the catalyst activation step. Contrary to other 
compounds described in the literature, such as $\left[\operatorname{Ir}(\mathrm{BINAP})\left\{1,2-c-\mathrm{C}_{6} \mathrm{H}_{10}\left(\mathrm{NH}_{2}\right)_{2}\right\}(\mathrm{H})(\mathrm{Cl})\right]^{+}$and $\left[\operatorname{Ir}(\mathrm{COD})\left\{\mathrm{Ph}_{2} \mathrm{PhCH}(\mathrm{Ph}) \mathrm{CH}(\mathrm{Me}) \mathrm{NHMe}\right\}\right]^{+},{ }^{20,22}$ complexes $\mathbf{2}^{\mathbf{R}}$ also function quite well in aprotic solvents such as benzene or acetonitrile (so long as a strong base and $\mathrm{H}_{2}$ are present) ${ }^{70}$ demonstrating that hydrogenation, rather than transfer hydrogenation, takes place at least under these conditions.

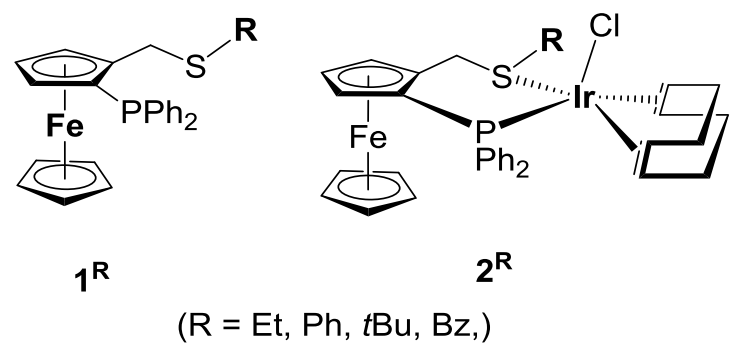

Scheme 2. Ligand and pre-catalyst object of this study.

In pursuit of further mechanistic information on the catalytic action of $2^{\mathrm{R}}$, we have tested a precatalyst that internally contains the needed methoxide base as a ligand, $[\operatorname{Ir}(\mathrm{OMe})(\mathrm{COD})] 2$, leading to the conclusion that the active catalyst cannot be a neutral complex. We have also carried out additional experiments on non-enolizable substrates. Finally, a DFT analysis provided a rationalization of the experimental observations. The key result is that the hydrogenation cycle requires the generation of anionic species. This constitutes a new paradigm in the hydrogenation of carbonyl compounds, where access to an efficient outer sphere mechanism does not require the presence of deprotonatable ligands on the catalytic metal.

\section{Results and Discussion}




\section{Experimental studies}

\subsection{Chloride vs. methoxide}

In order to probe the effect of the strong base, we have now tested a pre-catalyst that internally contains the needed strong base for the generation of neutral chloride-free species. As previously reported, ${ }^{70}$ compounds $2^{\mathrm{R}}(\mathrm{R}=\mathrm{Et}, \mathrm{Ph}, t \mathrm{Bu}, \mathrm{Bz})$ display high activity in the hydrogenation of substituted acetophenones when used in $i \mathrm{PrOH}$ in combination with a strong base ( $\mathrm{NaOMe}, \mathrm{KOH}$ or $\mathrm{KO} t \mathrm{Bu}$ ) under an $\mathrm{H}_{2}$ atmosphere (30 bars) at room temperature or below (e.g. see run 1 in Table 1). Run 2 shows that the in situ generated chloride precatalyst yields the same activity as the isolated complex $\mathbf{2}^{\mathbf{E t}},{ }^{70}$ thus it is not necessary to isolate compounds $\mathbf{2}^{\mathbf{R}}$. Runs 3-5 confirm the need of both the ligand and a strong base for activity. Hence, the methoxide analogue was also generated in situ from $[\operatorname{Ir}(\mathrm{OMe})(\mathrm{COD})]_{2}$ and $\mathbf{1}^{\mathrm{Et}}$, without attempting the isolation of putative $\left[\operatorname{Ir}(\mathrm{OMe})(\mathrm{COD})\left(\mathbf{1}^{\mathrm{Et}}\right)\right]$. Contrary to our expectations, the $[\operatorname{Ir}(\mathrm{OMe})(\mathrm{COD})]_{2} / \mathbf{1}^{\mathrm{Et}}$ catalyst showed only very small activity (run 6), comparable to that of the corresponding chlorido system (run 4) and no activity was recorded in the absence of ligand (run 7). However, full activity was restored in the presence of both the ligand and the external base (run 8). When the enantiomerically pure ligand was used (run 9), the enantiomeric excess of the hydrogenation product (67\%) was identical to that observed for the reaction catalyzed by $2^{\mathrm{Et}} / \mathrm{NaOMe}$ under the same conditions, ${ }^{70}$ suggesting generation of the same active species. Hence, the chlorido ligand in $[\mathrm{IrCl}(\mathrm{COD})]_{2} / \mathbf{1}^{\mathbf{E t}}$ or $\mathbf{2}^{\mathbf{E t}}$ has no active role in catalysis. This conclusion matches with that of another recent study ${ }^{81}$ of the related $\mathrm{Rh}^{\mathrm{I}}$ complexes, where complexes $\left[\mathrm{Rh}(\mathrm{COD})\left(\mathbf{1}^{\mathbf{t} \mathbf{B u}}\right)\right]^{+} \mathrm{BF}_{4}^{-}$and $\left[\mathrm{RhCl}(\mathrm{COD})\left(\mathbf{1}^{t \mathbf{B u}}\right)\right]$ whereas shown to feature the same catalytic behavior.

Table 1. Results of catalytic runs for the hydrogenation of $\mathrm{PhCOR}$ to $\mathrm{PhCH}(\mathrm{R}) \mathrm{OH}{ }^{a}$ 


\begin{tabular}{|c|c|c|c|c|c|c|}
\hline run & catalyst & ligand & Additive & $\mathbf{R}$ & Time (h) & Conv.(\%) ${ }^{b}$ \\
\hline $1^{c}$ & $2^{\mathrm{Et}}$ & - & $\mathrm{NaOMe}$ & $\mathrm{CH}_{3}$ & 5 & $>99$ \\
\hline 2 & {$[\mathrm{Ir}(\mathrm{COD}) \mathrm{Cl}]_{2}$} & $\mathbf{1}^{\mathrm{Et}}$ & $\mathrm{NaOMe}$ & $\mathrm{CH}_{3}$ & 5 & $>99$ \\
\hline $3^{c}$ & $2^{\mathrm{Et}}$ & - & - & $\mathrm{CH}_{3}$ & 5 & 0 \\
\hline 4 & {$[\operatorname{Ir}(\mathrm{COD}) \mathrm{Cl}]_{2}$} & $1^{\mathrm{Et}}$ & - & $\mathrm{CH}_{3}$ & 5 & 7 \\
\hline 5 & {$[\operatorname{Ir}(\mathrm{COD}) \mathrm{Cl}]_{2}$} & - & - & $\mathrm{CH}_{3}$ & 5 & 0 \\
\hline 6 & {$[\operatorname{Ir}(\mathrm{COD})(\mathrm{OMe})]_{2}$} & $1^{\mathrm{Et}}$ & - & $\mathrm{CH}_{3}$ & 5 & 7 \\
\hline 7 & {$[\operatorname{Ir}(\mathrm{COD})(\mathrm{OMe})]_{2}$} & - & - & $\mathrm{CH}_{3}$ & 5 & 0 \\
\hline 8 & {$[\operatorname{Ir}(\mathrm{COD})(\mathrm{OMe})]_{2}$} & $1^{\mathrm{Et}}$ & $\mathrm{NaOMe}$ & $\mathrm{CH}_{3}$ & 5 & 98 \\
\hline 9 & {$[\operatorname{Ir}(\mathrm{COD})(\mathrm{OMe})]_{2}$} & $\mathbf{1}^{\mathrm{Et} d}$ & $\mathrm{NaOMe}$ & $\mathrm{CH}_{3}$ & 5 & $81^{e}$ \\
\hline 10 & {$[\operatorname{Ir}(\mathrm{COD}) \mathrm{Cl}]_{2}$} & $\mathbf{1}^{\mathrm{Et}}$ & $\mathrm{NaOMe}$ & $\mathrm{CF}_{3}$ & 2 & 42 \\
\hline 11 & {$[\mathrm{Ir}(\mathrm{COD}) \mathrm{Cl}]_{2}$} & $1^{\mathrm{Et}}$ & $\mathrm{NaOMe}$ & $t \mathrm{Bu}$ & 5 & 25 \\
\hline
\end{tabular}

${ }^{a}$ Reaction conditions: racemic catalyst, $6.4 \cdot 10^{-3} \mathrm{mmol}$; additive, $3.2 \cdot 10^{-2} \mathrm{mmol}$; acetophenone, $3.2 \mathrm{mmol}$; under 30 bars at $27^{\circ} \mathrm{C}$ in $2 \mathrm{~mL}$ of isopropanol. ${ }^{b}$ Conversions determined by $\mathrm{GC} ; 100 \%$ selectivity in (R/S)-PhCH(R)OH. ${ }^{c}$ From ref. ${ }^{70} \cdot{ }^{\mathrm{d}}$ Enantiomerically pure ligand $(\mathrm{S}) ;{ }^{e} e e=67 \%(\mathrm{~S})$.

\subsection{Non enolizable substrates}

For certain hydrogenation catalysts, evidence has been advanced in favor of a mechanism proceeding through a metal-assisted enolization of the ketone, followed by hydrogenation of the enol $\mathrm{C}=\mathrm{C}$ unsaturation. ${ }^{82,83}$ Two non-enolizable ketones, PhCOR with $\mathrm{R}=\mathrm{CF}_{3}$ and $t \mathrm{Bu}$, have therefore been used as substrates for the hydrogenation catalyzed by $[\operatorname{IrCl}(\mathrm{COD})]_{2} / \mathbf{1}^{\mathrm{Et}}$ (runs 10 and 11 , respectively). Although the catalytic activity is reduced for these systems, probably because of electronic effects in the former case and steric hindrance in the latter one, hydrogenation does take place. Hence, a hydrogenation mechanism without the need of tautomerization is energetically viable, at least for these two substrates. 


\subsection{Fate of the cyclooctadiene}

Additional information on the nature of the catalyst activation process was sought by treating the $[\mathrm{IrCl}(\mathrm{COD})]_{2} / \mathbf{1}^{\mathrm{Et}}$ mixture with $\mathrm{H}_{2}$ in the absence of substrate. This reaction results in COD elimination selectively as cyclooctene (observed by gas-chromatography), with no detectable trace of cyclooctane. Thus, hydrogenation of the COD ligand takes place at the initial stages of the hydrogenation catalysis and the cyclooctene product does not have sufficient binding affinity with the Ir center under these conditions to be further hydrogenated.

\section{Mechanistic considerations}

In the absence of base, activation of either $[\operatorname{IrCl}(\mathrm{COD})]_{2} / \mathbf{1}^{\mathrm{Et}}$ or $[\operatorname{Ir}(\mathrm{OMe})(\mathrm{COD})]_{2} / \mathbf{1}^{\mathbf{E t}}$ with $\mathrm{H}_{2}$ in a coordinating solvent such as $i \mathrm{PrOH}$, presumably generates $\left[\operatorname{Ir}(\mathrm{H})_{2}\left(\mathbf{1}^{\mathrm{Et}}\right)(i \mathrm{PrOH})_{2}\right]^{+}$after COD hydrogenation and cyclooctene expulsion. Related species have been observed for the rhodium

analogue by ${ }^{1} \mathrm{H}$ NMR using para-hydrogen induced polarization. ${ }^{84}$ Subsequent deprotonation by the external or internal base could lead for instance to $\left[\operatorname{IrH}\left(1^{\mathrm{Et}}\right)(i \mathrm{PrOH})\right]$ or to the related alkoxide derivative $\left[\operatorname{Ir}(\mathrm{O} i \mathrm{Pr})\left(\mathbf{1}^{\mathrm{Et}}\right)(i \mathrm{PrOH})\right]$, from which a host of different mechanisms may be imagined. When the reaction is carried out in an aromatic hydrocarbon solvent, $\eta^{2}$-arene coordination or alkoxide bridge formation can temporarily saturate the iridium coordination sphere, although the vacant position can then be saturated by the ketone substrate or by the alcohol product. This would well rationalize the observation of catalytic activity even in a non-coordinating solvent. However, this neutral system cannot be the catalytically active species, because it should be equally accessible also from the $[\operatorname{Ir}(\mathrm{OMe})(\mathrm{COD})]_{2} / \mathbf{1}^{\mathrm{Et}}$ mixture. The need of additional base to promote the catalytic activity points to further deprotonation with the generation of anionic species. 
Numerous attempts have been made to identify the nature of the catalytically active species in solution by generation from $[\operatorname{Ir}(\mathrm{OMe})(\mathrm{COD})]_{2} / \mathbf{1}^{\mathrm{Et}}$ and strong base in the absence of substrate, under a variety of different conditions and in different solvents and notably to find supporting evidence for its anionic nature, using NMR spectroscopic and mass spectrometric methods. Because of the compounds extreme sensitivity, we have so far been unable to isolate or spectroscopically identify this species. Therefore, we have used computational chemistry to explore the likely nature and structure of a putative anionic catalyst.

\section{DFT computational study}

\subsection{Cationic vs. neutral vs. anionic systems.}

Exploratory investigations used a simpler model of 1, henceforth abbreviated as (PS), generated by replacing the ferrocene linker with a $-\mathrm{CH}=\mathrm{CH}-$ linker and the phenyl groups by $\mathrm{H}$ atoms (see Scheme 3), but relevant systems were subsequently calculated with the real ligand. The calculations included the effect of solvation by optimization in a polarizable continuum (methanol being used as the solvent) and the base was modelled by $\left[\mathrm{MeO}(\mathrm{MeOH})_{\mathrm{n}-1}\right]^{-}$clusters, yielding $\left[(\mathrm{MeOH})_{\mathrm{n}}\right],{ }^{85}$ with $n$ up to 6 . The proton transfer Gibbs energies are greatly dependent on $n$ for small $n$ values but then converge, remaining essentially unchanged on going from 5 to 6 (see details in the SI). Only the values for $n=6$ will be presented. Views of all calculated structures are in the SI and the energy results are presented in Figure 1. Note that these computational investigations are only meant to assess the relative stability of various species and do not intend to suggest the mechanism leading from the pre-catalyst to the most stable species. 


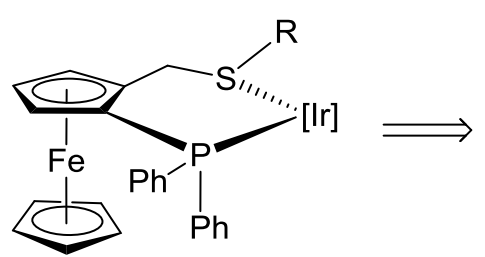

real system

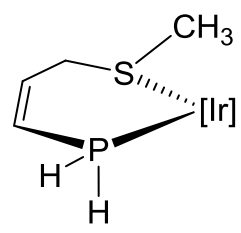

simpler model

Scheme 3. Ligand simplification used for the initial computational investigations.

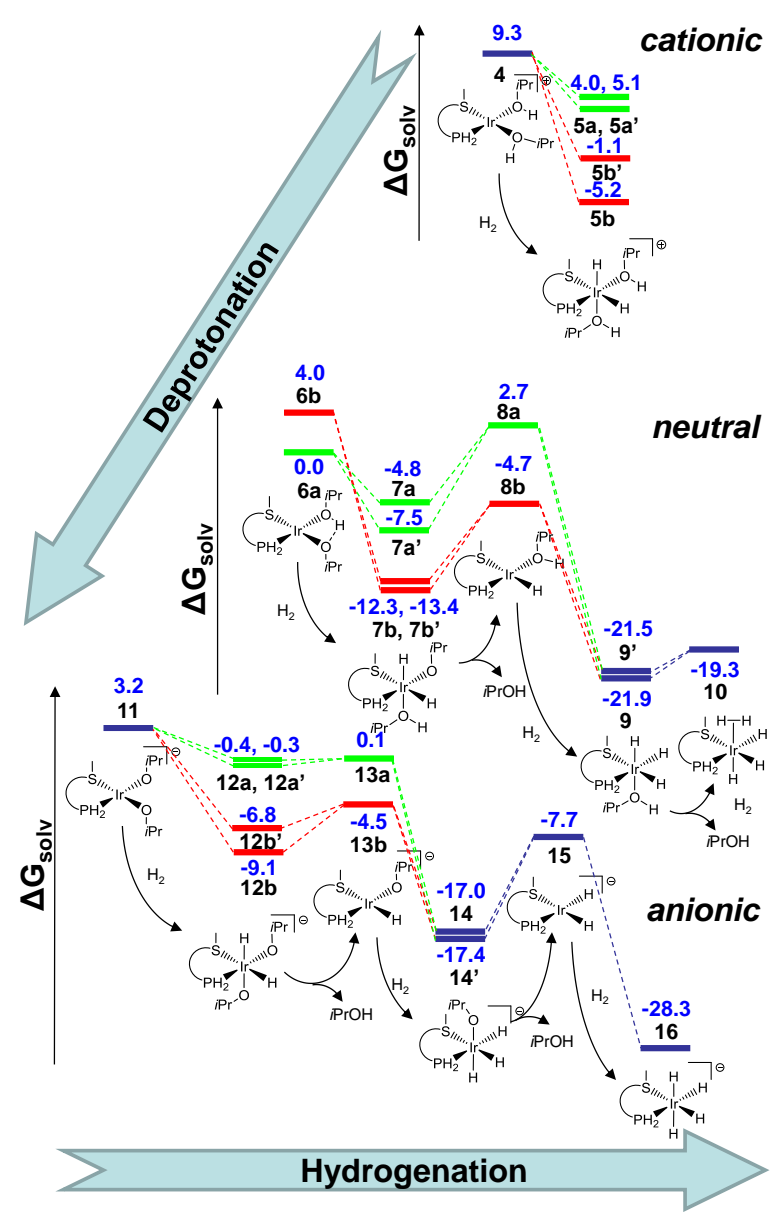

Figure 1. Relative energy in methanol solution $\left(\Delta \mathrm{G}_{\mathrm{MeOH}}\right.$ in $\left.\mathrm{kcal} / \mathrm{mol}\right)$ of various species generated from $\left.[\operatorname{Ir}(\mathrm{COD})(\mathrm{PS})]^{+} / \mathrm{H}_{2} /\left[\mathrm{MeO}(\mathrm{MeOH})_{5}\right]^{-}\right)$. Only the structures of the lowest energy isomers are shown. See SI for the others. Color coding: green, (a isomers, $\mathrm{H}$ trans to P); red (b isomers, H trans to S); blue (numbers with no letter, primed numbers for isomers), symmetric systems. 
Starting from the cationic $[\operatorname{Ir}(\mathrm{PS})(\mathrm{COD})]^{+}(\mathbf{3})$, COD removal by hydrogenation coupled to isopropanol coordination yields $\left[\operatorname{Ir}(\mathrm{PS})(\mathrm{irOH})_{2}\right]^{+}(\mathbf{4})$. This process is undoubtedly exothermic and the formation of cyclooctene has been experimentally demonstrated, therefore no calculations were carried out on this step. Complex 4 is $9.3 \mathrm{kcal} / \mathrm{mol}$ higher than the neutral system $[\operatorname{Ir}(\mathrm{O} i \mathrm{Pr})(\mathrm{PS})(i \mathrm{PrOH})](i \mathrm{PrOH}$ trans to $\mathrm{P}$, isomer 6a), which is taken as the reference point on the G scale. $\mathrm{H}_{2}$ oxidative addition to 4 to yield $\left[\operatorname{IrH}_{2}(\mathrm{PS})(i \mathrm{PrOH})_{2}\right]^{+}(5)$ can occur in 4 different ways, each one leading to a different stereoisomer. Indeed, $\mathrm{H}_{2}$ may add along the P-Ir-O or the S-Ir-O' vector and in each case the additions either above or below the coordination plane are diastereotopically related because of the ligand chirality. Of the four possible isomers, $\mathbf{5 a}$ and $\mathbf{5 a}$ ' with a hydride ligand trans to $\mathrm{P}$ and $\mathbf{5 b}$ and $\mathbf{5 b}$ ' with a hydride ligand trans to $\mathrm{S}$, the two latter ones have lower energy because the strongest trans labilizing ligand (hydride) is located trans to the less strongly bonded donor atom (S). Figure 1 illustrates the energy of all isomers but details only the geometry of the lowest energy one. All chemical drawings are provided in the SI.

Neutral and anionic systems can be obtained by single and double deprotonation. In the neutral manifold, two isomers of $[\operatorname{Ir}(\mathrm{O} i \operatorname{Pr})(\mathrm{PS})(i \operatorname{PrOH})](\mathbf{6 a}$ and $\mathbf{6 b})$ are generated by deprotonation of $\mathbf{4}$, involving either the isopropanol ligand located trans to $\mathrm{S}$ (isomer $\mathbf{6 a}$ ) or that trans to $\mathrm{P}(\mathbf{6 b})$. The deprotonation process is energetically favorable and the lowest energy isomer is $\mathbf{6 a}$ where the isopropoxide, which is a stronger donor than isopropanol, is located trans to the weaker donor S atom. $\mathrm{H}_{2}$ oxidative addition to 6 to generate $\left[\operatorname{IrH}_{2}(\mathrm{O} i \mathrm{Pr})(\mathrm{PS})(i \mathrm{PrOH})\right](7)$ is also energetically favorable and may occur in four different ways, by analogy to the $\mathrm{H}_{2}$ oxidative addition to the protonated analogue 4 examined above. The lowest energy isomer (7b) features the strongest donor ligand (hydride) trans to S. These four compounds can also be generated by deprotonation of the corresponding isomers of $\mathbf{5}$. It now possible to envisage $i \mathrm{PrOH}$ reductive elimination from 
7 to yield two isomers of $[\operatorname{IrH}(\mathrm{PS})(i \mathrm{PrOH})](\mathbf{8 a}$ and $\mathbf{8 b})$, which may also be generated by deprotonation of $\mathbf{5}$ at the metal with concomitant $i \mathrm{PrOH}$ release. Isomer $\mathbf{8 b}$ with the hydride ligand trans to $\mathrm{S}$ is the more stable one. The $i \mathrm{PrOH}$ reductive elimination process is endoergic by ca. 7 $\mathrm{kcal} / \mathrm{mol}$. It is then possible to oxidatively add $\mathrm{H}_{2}$ to $\mathbf{8 a} / \mathbf{b}$ to give $\left[\operatorname{IrH}_{3}(\mathrm{PS})(i \mathrm{PrOH})\right]$ with three $f a c$ $\mathrm{H}$ ligands (9 and $\mathbf{9}$, both generated from either $\mathbf{8 a}$ or $\mathbf{8 b}$ ). This process is very exothermic, even when starting from the most stable isomer $\mathbf{8 b}(\Delta G=-17.2 \mathrm{kcal} / \mathrm{mol})$. The two products have a symmetric substitution pattern trans to the PS ligand, therefore only two isomers are possible, differing by the placement of the axial $\mathrm{H}$ and $i \mathrm{PrOH}$ ligands above and below the enantiomeric equatorial plane. Putative mer isomers of 9 would be disfavored because of strong trans influence of the mutually trans $\mathrm{H}$ atoms and have not been considered. Another possible tautomer, the 7coordinate $\left[\mathrm{IrH}_{4}(\mathrm{O} i \mathrm{Pr})(\mathrm{PS})\right]$ of formally $\mathrm{Ir}^{\mathrm{V}}$, converged to a nonclassical octahedral isomer of $\mathrm{Ir}^{\mathrm{III}}$, $\left[\mathrm{IrH}_{2}(\mathrm{O} i \mathrm{Pr})\left(\mathrm{H}_{2}\right)(\mathrm{PS})\right](9$ "), at much higher energy and is not included in Figure 1. Substitution of $i$ PrOH with $\mathrm{H}_{2}$ in 9 or 9' leads to $\left[\mathrm{IrH}_{3}\left(\mathrm{H}_{2}\right)(\mathrm{PS})\right]$, 10. A classical pentahydride tautomer of this compound (10') was found higher in energy (see SI). Hence, the lowest energy species in the neutral manifold is the trihydride complex $\mathbf{9}$. This will be considered as the putative catalyst resting state in hydrogenation cycles carried out in the absence of base (vide infra).

Concerning the anionic species, $\left[\operatorname{Ir}(\mathrm{O} i \operatorname{Pr})_{2}(\mathrm{PS})\right]^{-}(\mathbf{1 1})$ is obtained by deprotonation of $\mathbf{6 a}$ or $\mathbf{6 b}$, $\left[\mathrm{IrH}_{2}(\mathrm{O} i \mathrm{Pr})_{2}(\mathrm{PS})\right]^{-}\left(\mathbf{1 2}\right.$, four isomers) by $\mathrm{H}_{2}$ oxidative addition to $\mathbf{1 1}$ or by deprotonation of $\mathbf{7}$, $[\mathrm{IrH}(\mathrm{O} i \mathrm{Pr})(\mathrm{PS})]^{-}$(13, two isomers) by $i \mathrm{PrOH}$ reductive elimination from $\mathbf{1 2}$ or by deprotonation of $\mathbf{8},\left[\mathrm{IrH}_{3}(\mathrm{O} i \mathrm{Pr})(\mathrm{PS})\right]^{-}\left(\mathbf{1 4}\right.$, two isomers) by $\mathrm{H}_{2}$ oxidative addition to $\mathbf{1 3}$ or by deprotonation of $\mathbf{9}$, $\left[\mathrm{IrH}_{2}(\mathrm{PS})\right]^{-}(\mathbf{1 5})$ by $i \mathrm{PrOH}$ reductive elimination from 14, and finally $\left[\mathrm{IrH}_{4}(\mathrm{PS})\right]^{-}(\mathbf{1 6})$ by $\mathrm{H}_{2}$ oxidative addition to $\mathbf{1 5}$ or by deprotonation of $\mathbf{1 0}$. Wherever there are isomeric possibilities, as noted above for the cationic and for the neutral systems, the most stable isomer is always the one 
placing the stronger $\sigma$ donor ligand trans to $\mathrm{S}$ and the weaker one trans to $\mathrm{P}$. Also parallel to the trends already noted for the cationic and neutral manifolds, the $\mathrm{H}_{2}$ oxidative addition processes are exoergic and the $i \mathrm{PrOH}$ reductive elimination processes are endoergic, though by a lesser amount. This phenomenon yields a trend of decreasing energy upon substitution of OiPr ligands with hydrides by the $\mathrm{H}_{2}$ oxidative addition - $i \mathrm{PrOH}$ reductive elimination sequence.

The most important energetic result, however, concerns the deprotonation. While for certain stoichiometries the most stable system is the neutral one (e.g. $\mathbf{6 a} v s . \mathbf{4}$ and $\mathbf{1 1} ; \mathbf{7 b} v s . \mathbf{5 b}$ and $\mathbf{1 2 b}$; $\mathbf{9} v s . \mathbf{1 4}$ ) and the deprotonation of $\mathbf{8 b}$ to $\mathbf{1 3 b}$ is nearly thermoneutral, the tetrahydrido system $\mathbf{1 6}$ is much more stabilized than the protonated neutral version $\mathbf{1 0}$ and is by far the most stabilized species overall. It is therefore likely to correspond to the catalyst resting state. Note that $\mathbf{1 6}$ is isoelectronic with the $\left[\mathrm{IrH}_{4}\left(\mathrm{PR}_{3}\right)_{2}\right]^{-}(\mathrm{R}=i \mathrm{Pr}, \mathrm{Ph})$ anions, ${ }^{86,87}$ which were isolated and fully characterized as salts of crown-ether-stabilized alkali metals. ${ }^{86,88}$

After obtaining preliminary indications of the likely identity of the most stable solution species from the above exploratory investigations, selected calculations were carried out on the full system in order to assess the importance of electronic and steric effects associated to the ligand simplification. The calculations were carried out using $\mathbf{1}^{\mathbf{P h}}$ as ligand at the full quantum mechanical level. The relative energies for all systems investigated did not greatly vary relative to those of the simpler model: cationic $\mathbf{5} \mathbf{b}^{\mathbf{P h}}$ is at $-1.5 \mathrm{kcal} / \mathrm{mol}$ relative to $\mathbf{6 a}^{\mathbf{P h}}(v s .-5.2 \mathrm{kcal} / \mathrm{mol}$ for the model system), neutral $\mathbf{7} \mathbf{b}^{\mathbf{P h}}, \mathbf{9}^{\mathbf{P h}}$ and $\mathbf{1 0}^{\mathrm{Ph}}$ are respectively at $-11.9,-20.4$ and $-18.0 \mathrm{kcal} / \mathrm{mol}(v s .-13.5,-$ 21.9 and $-19.3 \mathrm{kcal} / \mathrm{mol}$ for the model system) and anionic $\mathbf{1 2}^{\mathbf{P h}}, \mathbf{1 4}^{\mathbf{P h}}$ and $\mathbf{1 6}^{\mathbf{P h}}$ are respectively at $-7.8,-16.2$ and $-25.8 \mathrm{kcal} / \mathrm{mol}(v s .-9.1,-17.4$ and -28.3 for the model system) showing a limited effect of the ligand backbone and substituents. The deprotonation from $10^{\mathrm{Ph}}$ to $16^{\mathrm{Ph}}$ is exoergic by $-7.8 \mathrm{kcal} / \mathrm{mol}\left(c f .-9.0 \mathrm{kcal} / \mathrm{mol}\right.$ for the model system). The geometry of $\mathbf{1 6}^{\mathbf{P h}}$, the lowest energy 
system calculated by this study, is depicted in Figure 2. To conclude, the DFT calculations suggests a thermodynamically favorable transformation of the iridium precatalysts $2^{\mathbf{R}}$ to the octahedral anionic tetrahydride complex $16^{\mathbf{R}}$ in the presence of $\mathrm{H}_{2}$ and a strong base in alcohol solvents.

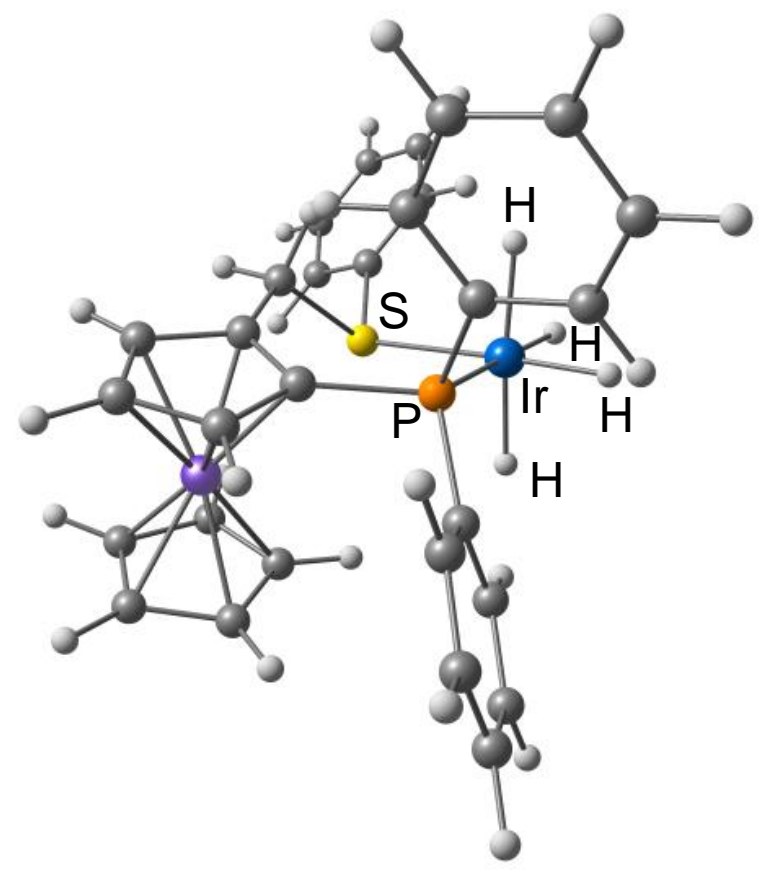

Figure 2. View of the optimized geometry for the anionic complex $\left[\operatorname{IrH}_{4}\left(\mathbf{1}^{\mathbf{P h}}\right)\right]^{-}\left(\mathbf{1 6}^{\mathbf{P h}}\right)$.

\subsection{Relevance of anionic hydrides in hydrogenation catalysis.}

Quite some time ago, Pez et al. proposed the role of anionic hydride species in the catalytic hydrogenation of several oxygenated substrates, following the isolation and characterization of ortho-metallated $\left[\mathrm{K}\left(\mathrm{L}_{\mathrm{n}}\right)\right]\left[\mathrm{RuH}_{2}\left(\kappa^{2}: C, P-o-\mathrm{C}_{6} \mathrm{H}_{4} \mathrm{PPh}_{2}\right)\left(\mathrm{PPh}_{3}\right)_{2}\right]$ salts $\left(\mathrm{L}_{\mathrm{n}}=\text { solvent or crown ether }\right)^{89-}$ ${ }^{92}$ However, detailed investigations by Halpern et al. subsequently demonstrated that the Pez complex, which yields $\left[\mathrm{RuH}_{3}\left(\mathrm{PPh}_{3}\right)_{3}\right]^{-}$under $\mathrm{H}_{2},{ }^{93,94}$ is reversibly protonated to $\left[\mathrm{RuH}_{2}\left(\mathrm{H}_{2}\right)\left(\mathrm{PPh}_{3}\right)_{3}\right]$ in alcohol solvents and that the latter "tetrahydride" complex is the real catalyst. ${ }^{95}$ It seems that, after these debated contributions, the catalytic activity of anionic hydride complexes has no longer been considered. 
This Pez/Halpern contribution on the protonation state of the ruthenium-phosphine-hydride catalyst gives us the opportunity to benchmark our computational system. We have therefore computed the $\left[\mathrm{RuH}_{3}\left(\mathrm{PPh}_{3}\right)_{3}\right]^{-/} /\left[\mathrm{RuH}_{2}\left(\mathrm{H}_{2}\right)\left(\mathrm{PPh}_{3}\right)_{3}\right]$ system using the same base and solvent models and level of theory as for the above iridium study. Three isomeric structures were optimized for the neutral system, one non-classical ruthenium(II) complex with a dihydrogen ligand, $\left[\mathrm{RuH}_{2}\left(\mathrm{H}_{2}\right)\left(\mathrm{PPh}_{3}\right)_{3}\right]$, and two classical ruthenium(IV) tetrahydride complexes (see Figure 3). The lowest energy isomer is the non-classical one, in agreement with NMR evidence ${ }^{96,97}$ and with the solid state structure of a related complex. ${ }^{98}$ The next lowest isomer has a 1:3:3 (capped octahedron) geometry, an $\mathrm{H}$ atom capping the $f a c\left(\mathrm{PPh}_{3}\right)_{3}$ face $(3.2 \mathrm{kcal} / \mathrm{mol}$ higher than the nonclassical minimum). The less stable geometry can be described as a pentagonal bipyramid with two axial and one equatorial $\mathrm{PPh}_{3}$ ligands $(4.3 \mathrm{kcal} / \mathrm{mol}$ higher than the minimum). The anionic trihydride complex $\left[\mathrm{RuH}_{3}\left(\mathrm{PPh}_{3}\right)_{3}\right]^{-}$has a regular octahedral geometry with a $\mathrm{fac}$ arrangement of the hydrides and $\mathrm{PPh}_{3}$ ligands, as in the experimentally determined structures of [K(18-crown6)] $\left[\mathrm{RuH}_{3}\left(\mathrm{PPh}_{3}\right)_{3}\right]^{99}$ and $\left[\mathrm{Li}(\mathrm{THF})_{3}\right]\left[\mathrm{RuH}_{3}\left(\mathrm{PPh}_{3}\right)_{3}\right] .{ }^{100}$

Using the same base and conjugate acid models also employed to calculate the deprotonation energetics of the iridium system, namely the $\left[\mathrm{MeO}(\mathrm{MeOH})_{5}\right]^{-}$and $(\mathrm{MeOH})_{6}$ clusters, the deprotonation of the tetrahydride complex was found nearly thermoneutral $(-0.7 \mathrm{kcal} / \mathrm{mol})$. This result is in good agreement with the experimental evidence of an equilibrated process for the $\left[\mathrm{RuH}_{3}\left(\mathrm{PPh}_{3}\right)_{3}\right]^{-/}\left[\mathrm{RuH}_{2}\left(\mathrm{H}_{2}\right)\left(\mathrm{PPh}_{3}\right)_{3}\right]$ system (the experimental study used cyclohexanol in THF$\left.\mathrm{D}_{8}\right)^{95}$ and confirms that the Ir system has greater tendency to be anionic in basic alcohol relative to the Pez/Halpern Ru system. 
(4.3)

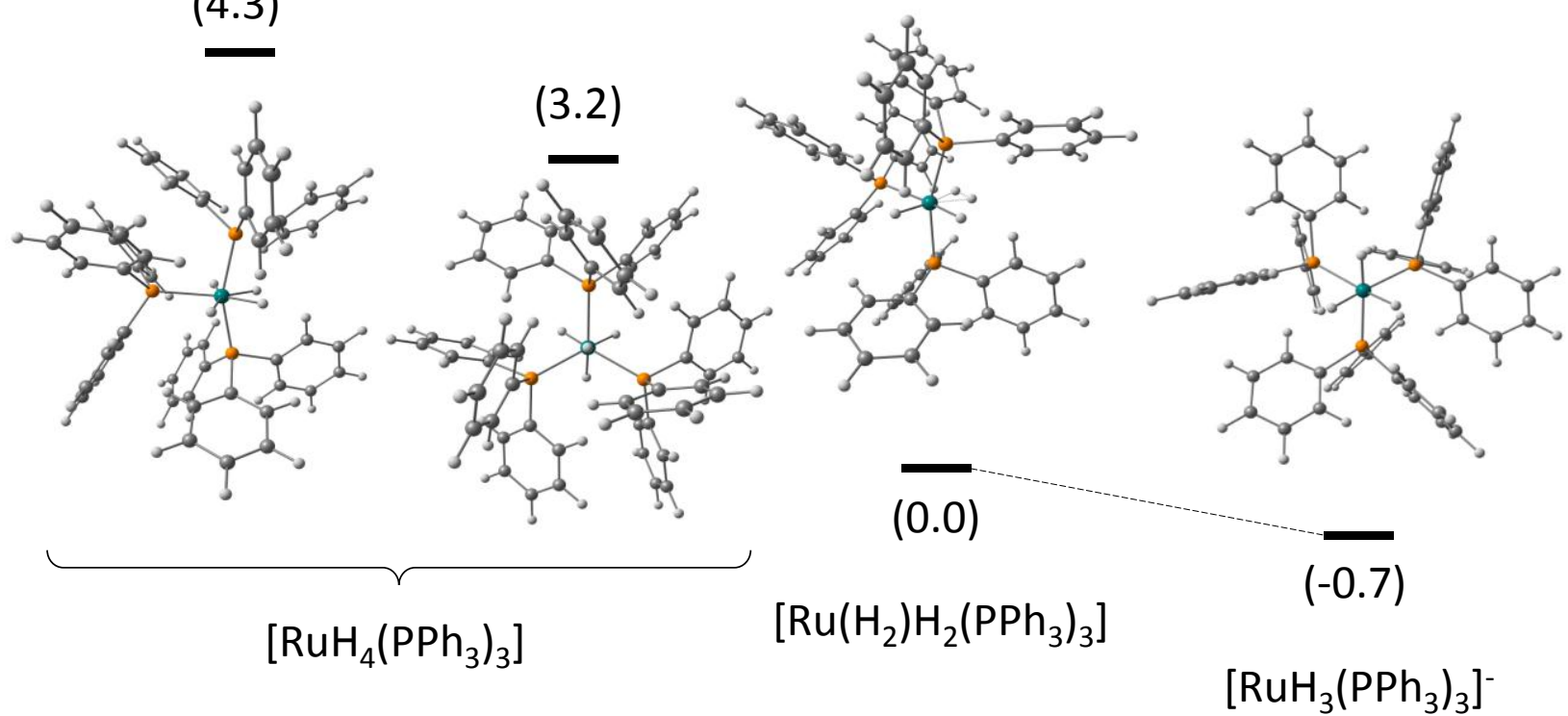

Figure 3. Relative energy in methanol solution $\left(\Delta \mathrm{G}_{\mathrm{MeOH}}\right.$ in $\left.\mathrm{kcal} / \mathrm{mol}\right)$ of three " $\mathrm{RuH}_{4}\left(\mathrm{PPh}_{3}\right)_{3}$ " isomers and of the deprotonated complex $\left[\mathrm{RuH}_{3}\left(\mathrm{PPh}_{3}\right)_{3}\right]^{-}$.

\subsection{Exploration of the hydrogenation mechanism from the anionic complex $\mathbf{1 6 .}$}

The hydrogenation of polar substrates may in principle occur by several different mechanisms. The most common ones are the inner-sphere, or coordination/insertion mechanism, which can be further classified into monohydride and dihydride mechanisms depending on the number of available hydrides on the catalytic metal and on the order of the insertion $/ \mathrm{H}_{2}$ activation/reductive elimination events, and an outer-sphere mechanism where the catalyst provides a hydride and a proton to the substrate without the need of substrate coordination, either concertedly (e.g. as in Scheme 1) or stepwise. The fundamental problem of system $\mathbf{1 6}$ is that neither a coordination site for a ketone coordination/insertion pathway nor a transferrable proton for the outer sphere pathway are available. A possible pathway, however, follows that recently presented by Dub et al. to reappraise the hydrogenation mechanism in the presence of Noyori's catalyst ${ }^{68}$ concluding that 
the base $(t \mathrm{BuOK})$ serves to deprotonate the amine in $\left[\mathrm{RuH}_{2}(\mathrm{BINAP})\left(\mathrm{NH}_{2} \mathrm{CHPhCHPhNH}_{2}\right)\right]$. The operating cycle occurs on a $[\mathrm{K}]^{+}\left[\mathrm{RuH}_{2}(\mathrm{BINAP})\left(\mathrm{NHCHPhCHPhNH}_{2}\right)\right]^{-}$system with stepwise hydride transfer, $\mathrm{H}_{2}$ coordination and proton transfer, whereas II (Scheme 1) is only an off-loop species.

Exploratory calculations (see Figure 4) where initially run on the simpler model and then repeated for the best cycle on the full system. Only the energies related to the full system are presented in Figure 4; once again, they do not substantially differ from those of the simpler model (see SI for the details). In addition, single-point calculations on all fixed optimized geometries were also repeated with a larger basis set (BS2, see Computational Details). The calculations used acetone as model substrate, methanol as model solvent and $\mathrm{Na}(\mathrm{MeOH})_{\mathrm{n}}{ }^{+}(\mathrm{n}=3)$ as counterion, while using cation models with $\mathrm{n}>3$ yielded higher $\mathrm{G}$ values for all systems. The cycle starts with a $\left[\mathrm{Na}^{+}(\mathrm{MeOH})_{3}{ }^{\cdots} \mathbf{1 6}^{\mathrm{Ph}}\right]$ ion pair $\left(\mathbf{1 7}^{\mathrm{Ph}}\right)$. The $\mathrm{Na}^{+}$cation anchors the ketone substrate in the first step $\left(17^{\mathrm{Ph}}-\mathbf{1 8}^{\mathrm{Ph}}\right)$. A very recent paper has also highlighted the role of the alkali metal cation, modeled as $\left[\mathrm{Na}\left(\mathrm{H}_{2} \mathrm{O}\right)_{6}\right]^{+}$, in the formate decarboxylation catalyzed by an iron pincer complex. ${ }^{101}$ The acetone adduct $18^{\mathrm{Ph}}$ is only slightly more stable, by $0.4 \mathrm{kcal} / \mathrm{mol}$, than the precursor $\mathbf{1 7}^{\mathrm{Ph}}$, but becomes less stable after recalculation with BS2. Hydride transfer follows to generate a $\mathrm{Na}^{+}-$ anchored alkoxide $\left(\mathbf{1 9}^{\mathrm{Ph}}\right)$ held in the Ir coordination sphere by $\sigma \mathrm{C}-\mathrm{H}$ coordination, which then rearranges to a more stable $\mu_{2}-\mathrm{O}$ isomer $\left(\mathbf{2 0}^{\mathbf{P h}}\right)$. In the next step, $\mathrm{H}_{2}$ displaces $\mathrm{O} i \mathrm{Pr}$ from the $\mathrm{Ir}$ coordination sphere to yield $\mathbf{2 2}^{\mathbf{P h}}$ through a van der Waals adduct $\left(\mathbf{2 1}^{\mathbf{P h}}\right)$ as a local minimum. The $\mathrm{H}_{2}$ ligand in $\mathbf{2 2}^{\mathbf{P h}}$ then delivers a proton to the $\mathrm{Na}^{+}$-bonded OiPr ligand to yield an isopropanol adduct $\mathbf{2 3}^{\mathrm{Ph}}$ and the cycle is completed by product expulsion. The resting state is the acetone adduct $\mathbf{1 8}^{\mathrm{Ph}}$ (or the tetrahydrido complex $\mathbf{1 7}^{\mathrm{Ph}}$ at the BS2 level) and the rate determining transition state, TS(21-22) ${ }^{\mathbf{P h}}$, corresponds to the isopropoxide substitution by $\mathrm{H}_{2}$. Therefore, the hydrogenation is 
in essence an outer sphere process with stepwise $\mathrm{H}^{-} / \mathrm{H}^{+}$transfer to the sodium-activated ketone, but the proton is not initially present on the catalyst; it is only provided in a later step after $\mathrm{H}_{2}$ activation. The cycle energy span is $18.2 \mathrm{kcal} / \mathrm{mol}$ (or $17.3 \mathrm{kcal} / \mathrm{mol}$ at the $\mathrm{BS} 2 \mathrm{level}$ ), in good agreement with the observed high TOF at room temperature. ${ }^{70}$ Indeed, for a TON of 500 in $2 \mathrm{~h}$ at $298 \mathrm{~K}$, a span of $19.0 \mathrm{kcal} / \mathrm{mol}$ can be calculated using the Eyring equation, but the initial TOF is greater for an estimated span closer to the computed value. Note that the alkali metal cation plays a crucial role in this mechanism, insuring the ketone activation in intermediate 18. Evidence in favor of an active role played by the alkali cation has been documented for $\mathrm{Ru}^{\mathrm{II}}$-diamine-based hydrogenation catalyst. ${ }^{102,103}$

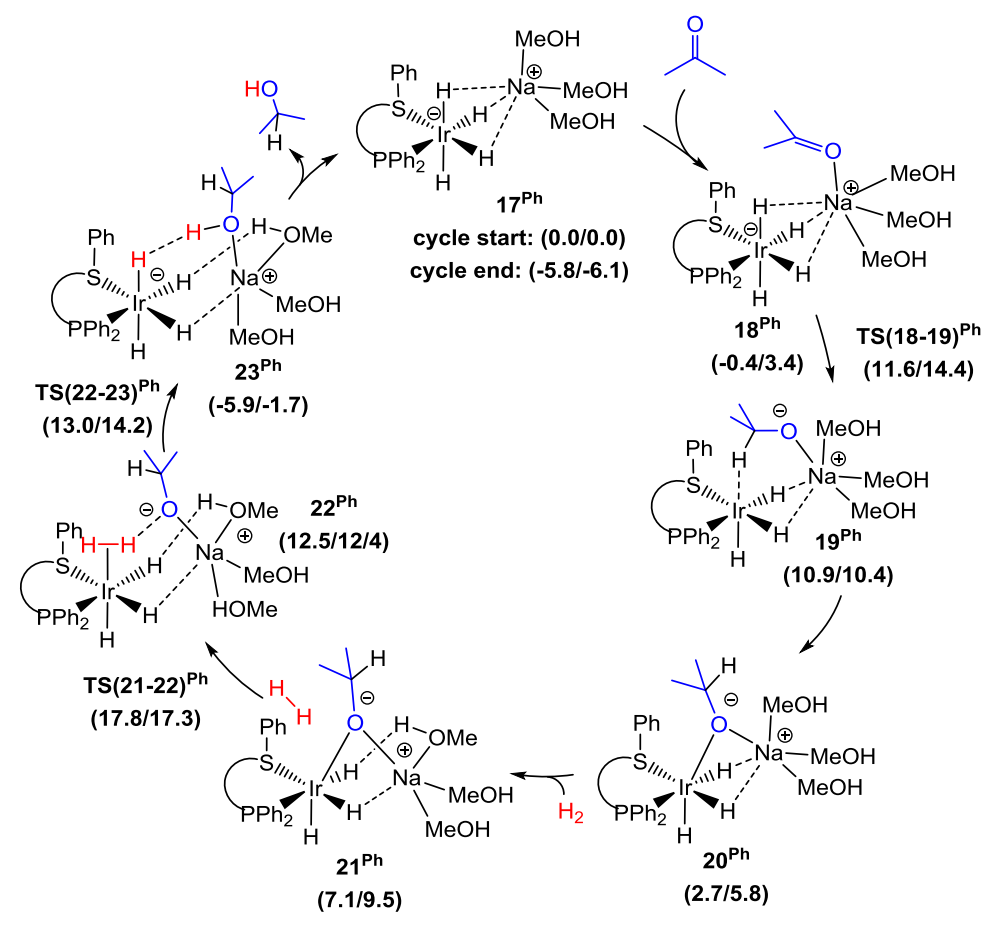

Figure 4. Computed cycle for acetone hydrogenation catalyzed by $\left[\mathrm{Na}(\mathrm{MeOH})_{3}\right]\left[\mathrm{IrH}_{4}\left(\mathbf{1}^{\mathbf{P h}}\right)\right]\left(\mathbf{1 7}^{\mathbf{P h}}\right)$.

For each species the Gibbs energies (optimized geometry with BS1/fixed geometry with BS2) in $\mathrm{kcal} / \mathrm{mol}$ are given in parentheses below the compound symbol. 
It is of interest to compare the energy profile of this cycle with that recently presented by Dub et al. for the related $[\mathrm{K}]^{+}\left[\mathrm{RuH}_{2}(\mathrm{BINAP})(\mathrm{NHCHPhCHPhNH} 2)\right]^{-}$species. ${ }^{68}$ For the deprotonated Noyori catalyst, where a naked $\mathrm{K}^{+}$cation was used as opposed to our more realistic $\mathrm{MeOH}-$ solvated $\mathrm{Na}^{+}$cation, the calculated rate-determining transition state was the ketone insertion step. This step yields an intermediate where the alkoxide ligand is not coordinated to the alkali metal but rather forms a hydrogen bond with the $\mathrm{N}-\mathrm{H}$ group and a very weak $\sigma \mathrm{C}-\mathrm{H}$ coordination to the $\mathrm{Ru}$ center. In this way, there is no need to displace a strongly bonded anionic ligand to coordinate $\mathrm{H}_{2}$, as opposed to our calculated cycle in which the alkoxide rearranges to bridge the Ir and $\mathrm{Na}$ metals.

\subsection{Exploration of the hydrogenation mechanism from the neutral complex 9.}

The next question to be addressed is why catalysis is not efficient in the absence of a strong base. This means that the best available cycle from a neutral iridium complex must have a higher energy span than the anionic system presented above. The lowest energy species calculated within the neutral manifold (which is accessed from $[\operatorname{Ir}(\mathrm{OMe})(\mathrm{COD})]_{2} / \mathbf{1}^{\mathrm{Et}}$ when no strong base is added) is the trihydride complex $\mathbf{9}$. Therefore, this species is likely the resting state of any putative operating cycle under base-free conditions. Species 9 has an easily accessible vacant position for a coordination/insertion mechanism, made available by isopropanol dissociation, and also a proton (on the coordinated alcohol) for an outer sphere pathway.

Here, again, initial explorations were run on the simpler model system. Figure 5 shows the best cycle, while full details are provided in the SI. The first step is dissociative replacement of the isopropanol ligand to yield the acetone complex $\mathbf{2 5}$ via the coordinatively unsaturated trihydride complex 24. Isopropanol dissociation has a very small energy cost $(3.8 \mathrm{kcal} / \mathrm{mol})$ because of the strong trans labilizing effect of the hydride ligand. The next step is hydride insertion to yield the 
alkoxide complex 26, of which two isomers are possible (26a with the alkoxide trans to S, represented in Figure 5, and $\mathbf{2 6} \mathbf{b}$ with the alkoxide trans to P). Isomer $\mathbf{2 6 \mathbf { b }}$ is actually lower in energy (at $3.8 \mathrm{kcal} / \mathrm{mol}$ relative to 9) because the two strongest trans labilizing ligands (the hydride and the $\mathrm{P}$ donor) are not mutually trans. However, isomer 26a leads to the lowest span cycle. Note that the isopropoxide ligand in 26a occupies the same equatorial position previously occupied by the hydride ligand: the axial ketone moves toward the equatorial plane concertedly with the insertion process. Therefore, this is an example of a real insertion, as opposed to a migratory insertion which characterizes the alkyl migration toward carbonyl groups in carbonylation processes or toward coordinated olefins in coordination polymerization processes. The catalytic cycle is then closed by $\mathrm{H}_{2}$ coordination yielding the adduct $\mathbf{2 7}$ ' and heterolytic activation, to transfer a proton to the coordinated isopropoxide and regenerate the hydride ligand via the ratedetermining transition state $\mathbf{T S}\left(\mathbf{2 7} \mathbf{a}^{\prime}-\mathbf{9}\right)$. This pathway involves coordination of $\mathrm{H}_{2}$ to the equatorial position with concomitant rearrangement of the isopropoxide ligand, which migrates toward the axial position. The alternative $\mathrm{H}_{2}$ coordination to the vacant axial site trans to the hydride ligand in 26a, while yielding a lower energy dihydrogen complex 27a, leads to a higher energy TS for the final heterolytic activation step. It is also possible to envisage an alternative outer sphere pathway for the concerted transfer of a proton from the coordinated isopropanol and a hydride ligand from 9 to the outer sphere acetone (indicated as the dashed pathway in Figure 5). This, however, would generate the same dihydro-isopropoxide complex 26. The coordination/insertion pathway that has already been found for this transformation is not the cycle rate-determining process. Therefore, even if the outer sphere $\mathrm{H}^{+} / \mathrm{H}^{-}$transfer were competitive with the coordination/insertion pathway, the cycle would remain limited by the rate of $\mathrm{H}_{2}$ activation and catalyst regeneration and the cycle energy span would not change. 


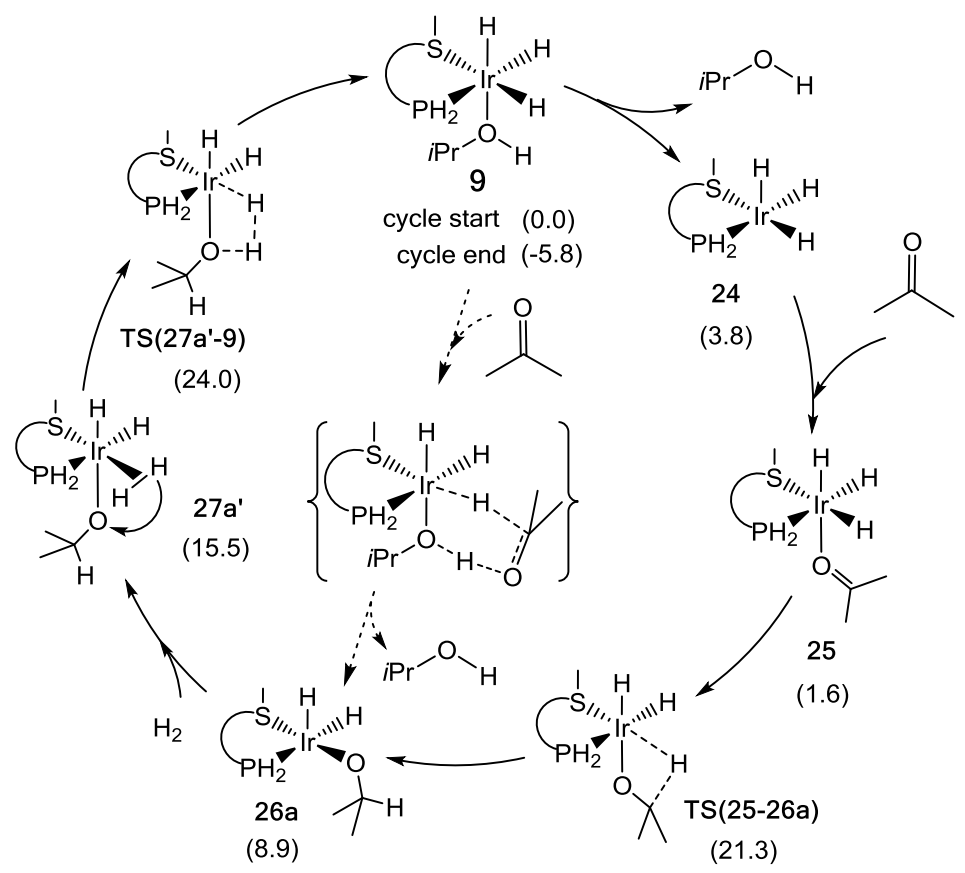

Figure 5. Best cycle for acetone hydrogenation catalyzed by $\left[\operatorname{IrH}_{4}\left(\mathbf{1}^{\mathrm{Ph}}\right)(i \mathrm{PrOH})\right](\mathbf{9})$. For each species the Gibbs energy in $\mathrm{kcal} / \mathrm{mol}$ is given in parentheses below the compound symbol.

The catalyst regeneration step from $\mathbf{2 6}$ to $\mathbf{9}$ can also be envisaged in another way, by inverting the $\mathrm{H}_{2}$ addition and $i \mathrm{PrOH}$ formation steps. Isopropoxide-hydride coupling could take place first, to generate the $[\mathrm{IrH}(\mathrm{PS})(i \mathrm{PrOH})]$ system $(\mathbf{8})$, followed by $\mathrm{H}_{2}$ oxidative addition. Thus, the mechanism would operationally become a "dihydride coordination/insertion" mechanism, as opposed to that shown in Figure 5 which is operationally a "monohydride coordination/insertion" mechanism. This possibility has also been explored on the model system, as shown in Figure 6. In

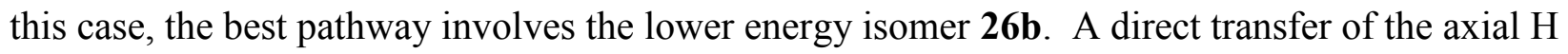
atom from Ir to the isopropoxide ligand requires a very high activation barrier, but the involvement of an additional solvent molecule, modelled with methanol, makes the process easier through a proton shuttle mechanism. 26b forms an H-bonded adduct with $\mathrm{MeOH}, \mathbf{2 6} \cdot \mathbf{M e O H}$, which leads 
to $\mathbf{8 b} \cdot \mathbf{M e O H}$ via TS(26b-8b) $\cdot \mathbf{M e O H}$. While this TS is at lower energy relative to the non-MeOH assisted mechanism, it still remains at higher energy than the alternative rate-determining TS for the monohydride mechanism in Figure 5. Once arrived at the $\operatorname{Ir}^{\mathrm{I}}$ hydride complex $\mathbf{8 b}$, the cycle is completed by $\mathrm{H}_{2}$ oxidative addition. The TS of this final step was not calculated since the high energy of TS(26b-8b) $\mathbf{M e O H}$ already makes this pathway less viable than the monohydride coordination/insertion mechanism of Figure 5.

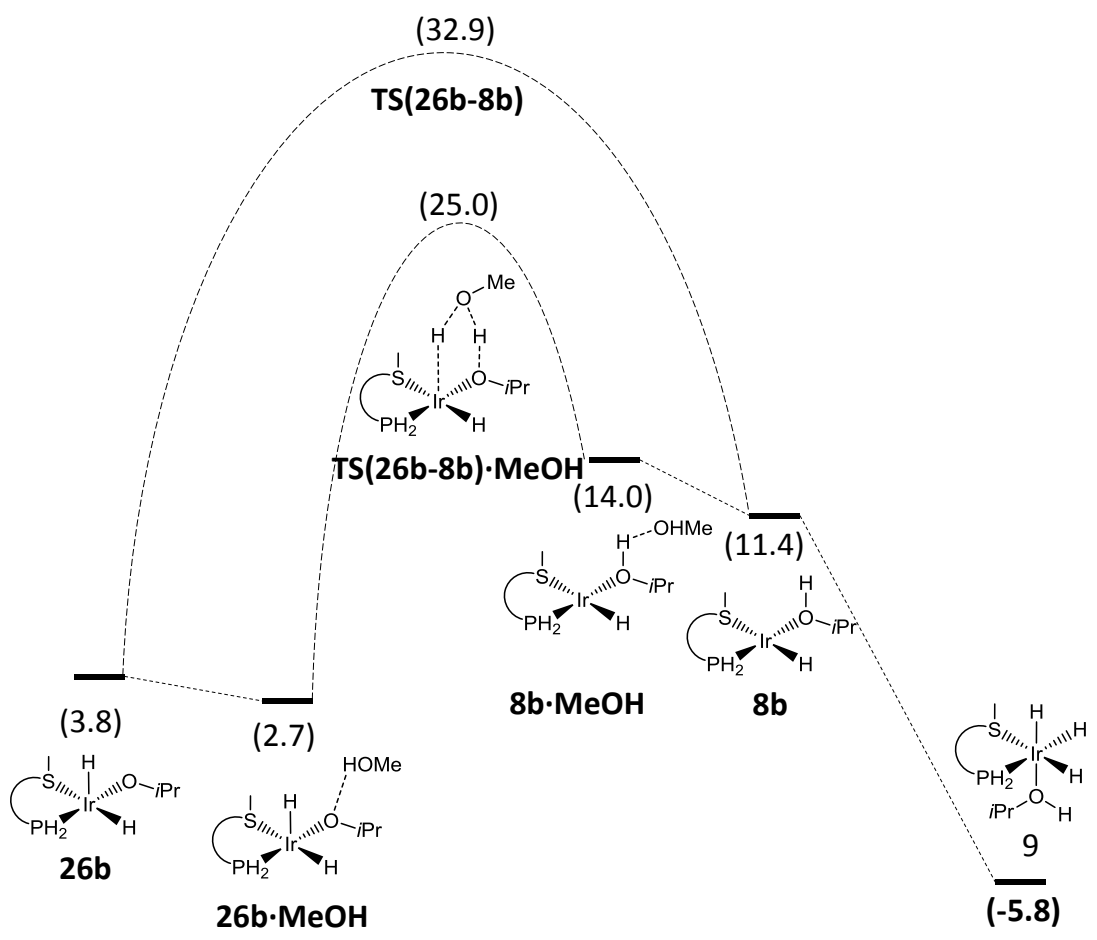

Figure 6. Alternative $\mathrm{O}-\mathrm{H}$ coupling/ $\mathrm{H}_{2}$ oxidative addition pathway for the regeneration of the resting state 9 from $\mathbf{2 6 b}$.

Following this preliminary exploration and given the general fidelity of the relative energies found for the real system to those of the simpler model (vide supra), the cycle energy span for the real system was assessed by calculating only the resting state $\mathbf{9}^{\mathbf{P h}}$, the key intermediate $\mathbf{2 7} \mathbf{a}^{\mathbf{P h}}$ for 
the best cycle (found at $19.6 \mathrm{kcal} / \mathrm{mol}$ from $\mathbf{9}^{\mathbf{P h}}$ ), and the rate determining transition state $\mathbf{T S}\left(\mathbf{2 7} \mathbf{a}^{\text {'- }}\right.$ 9) ${ }^{\mathbf{P h}}$, which was found at $26.3 \mathrm{kcal} / \mathrm{mol}$ from $9^{\mathbf{P h}}$. The energy span of this cycle is therefore 26.3 $\mathrm{kcal} / \mathrm{mol}$, i.e. $8.1 \mathrm{kcal} / \mathrm{mol}$ higher than that afforded by the anionic hydride $17^{\mathrm{Ph}}$. This result agrees with the experimental evidence that hydrogenation is efficient only when a strong base in present. The rate determining transition state for the neutral cycle is unfavorable because it involves heterolytic $\mathrm{H}_{2}$ activation in a structure with two mutually trans strong ligands ( $\mathrm{H}$ and $\mathrm{O} i \mathrm{Pr}$ ), whereas in the anionic cycle of Figure 4 the trans influence of these two ligands is alleviated by the alkoxide coordination to sodium and by the incipient substitution with $\mathrm{H}_{2}$.

\section{Conclusion}

We have experimentally demonstrated that the Ir ketone hydrogenation catalyst generated by activation of 2 cannot be a neutral iridium complex; the need of additional strong base suggests the generation of an anionic active complex. Calculations with the inclusion of implicit and explicit solvation effects and of the $\mathrm{Na}(\mathrm{MeOH})_{3}{ }^{+}$counterion suggest that the contact ion pair $\left[\mathrm{Na}^{+}(\mathrm{MeOH})_{3} \cdots \mathrm{Ir}^{-} \mathrm{H}_{4}(\mathrm{PS})\right]$, containing an anionic tetrahydride complex similar to already described bis(phosphine) systems, is the catalyst resting state and yield a cycle with an energy span consistent with the observed catalytic activity. The base has the dual role of generating the anionic complex and providing the Lewis acid co-catalyst for ketone activation. The cycle is similar to that recently presented by Dub et al. for the Noyori catalyst. ${ }^{68}$ However, we have demonstrated here for the first time that an outer sphere mechanism for ketone hydrogenation can be accessed also in the presence of "non-deprotonatable" supporting ligands, with the strong base playing a crucial role in the generation of anionic species through a sequence of $\mathrm{H}_{2}$ addition and deprotonation steps. 
Current work aims at studying the catalyst resting state by experimental methods. The role of the cation in the ketone activation will also be investigated in further combined experimental and computational work.

\section{Experimental Section}

All operations were carried out under an atmosphere of argon under standard glove-box and Schlenk-line techniques. Isopropanol was purified by distillation over $\mathrm{CaH}_{2}$. Ligand $\mathbf{1}^{\mathrm{Et}}$ and complex $2^{\text {Et }}$ were prepared as previously described ${ }^{69,}{ }^{104}$ Compounds $[\operatorname{Ir}(\mathrm{OMe})(\mathrm{COD})]_{2}$ (Strem), acetophenone (Aldrich, 99\%), 2,2,2-trifluoroacetophenone (Lancaster, 98\%) and phenyl tert-butyl ketone (Alfa Aesar, 98\%) were used as received.

General procedure for asymmetric hydrogenation. In a glove box, a solution of $6.4 \cdot 10^{-3}$ mmol of catalyst $\left(6.4 \cdot 10^{-3} \mathrm{mmol}\right.$ of $\mathbf{2}^{\mathrm{Et}}$ or $6.4 \cdot 10^{-3} \mathrm{mmol}$ of $\mathbf{1}^{\mathrm{Et}}$ and $6.4 \cdot 10^{-3} \mathrm{mmol}$ of metallic precursor), $3.2 \cdot 10^{-2} \mathrm{mmol}$ of $\mathrm{NaOMe}$ ( 5 equiv, if appropriate) and $0.37 \mathrm{~mL}$ of acetophenone (381 $\mathrm{mg}, 3.2 \mathrm{mmol}, 500$ equiv) in $2 \mathrm{~mL}$ of $i \mathrm{PrOH}$ was transferred into a $5 \mathrm{~mL}$ glass ampoule which was then placed into a stainless steel autoclave. The reaction vessel was pressurized to the required $\mathrm{H}_{2}$ pressure (30 bars) and stirred with a magnetic bar for the desired time at $27^{\circ} \mathrm{C}$ ). The reaction was stopped by release of pressure and quenching of the solution with $\mathrm{CH}_{2} \mathrm{Cl}_{2}$ at room temperature. The crude materials were obtained by evaporation of the solvent on rotavapor. The product was finally analysed by chiral GC (Supelco BETA DEX 225). 
Computational Details. The calculations were carried out within the DFT approach with the M06 functional, ${ }^{105}$ including an ultrafine integration grid, as implemented in Gaussian 09. ${ }^{106}$ All geometry optimizations were carried out using a basis set BS1, which consisted of the SDD basis set and ECP for the Ir and Fe atoms, ${ }^{107}$ augmented with $\mathrm{f}$ polarization functions $(\alpha=0.938$ and 2.462 , respectively), ${ }^{108}$ the $6-31 \mathrm{G}(\mathrm{d})$ basis set for all other heavy atoms, and the 6-31G(d,p) basis set for all $\mathrm{H}$ atoms. ${ }^{109}$ All molecules involved in the best catalytic cycle (see Results and Discussion) were also recalculated at their fixed geometries with a more extended basis set BS2 (same SDD functions for Ir and Fe, plus the 6-311++G(d,p) functions for all other atoms). The effect of the solvent was included by the SMD polarizable continuum ${ }^{110}$ in methanol $(\varepsilon=35.688)$ during the geometry optimizations with BS1 and single point calculations with BS2. All of the energies presented in the text are Gibbs energies in methanol $\left(\Delta \mathrm{G}_{\mathrm{MeOH}}\right)$. A correction of 1.95 $\mathrm{kcal} / \mathrm{mol}$ was applied to all $\mathrm{G}$ values to change the standard state from the gas phase (1 atm) to solution $(1 \mathrm{M}) .{ }^{111}$

\section{ASSOCIATED CONTENT}

Supporting Information. Additional details of the DFT calculations, Cartesian coordinates and views of the optimized geometries. This material is available free of charge via the Internet at http://pubs.acs.org.

\section{AUTHOR INFORMATION}

\section{Corresponding Author}

* Agustí Lledós: fax. +34-935912477 E-mail agusti@klingon.uab.es.

* Rinaldo Poli: fax. +33-561553003; E-mail rinaldo.poli@lcc-toulouse.fr. 


\section{Present Addresses}

$\dagger$ Current address: Division of Chemistry, Centre for Materials Science, University of Central Lancashire, Maudland Building, MB 50, United Kingdom.

† Current address: Institut de Chimie Moléculaire de l'Université de Bourgogne, UMR CNRS 5260, 9 Av Savary, BP 47870, F-21078 Dijon, France.

\section{Author Contributions}

The manuscript was written through contributions of all authors. All authors have given approval to the final version of the manuscript.

\section{Notes}

The authors declare no competing financial interest.

\section{ACKNOWLEDGMENT}

We thank the European Commission through the HYDROCHEM program (contract HPRN-CT2002-00176) for support of this work. Additional bilateral support (LEA, Toulouse-Barcelona) and National support from the CNRS (France), from the Institut Universitaire de France, and from the MINECO (project CTQ2014-54071-P, Spain) is also gratefully acknowledged.

\section{REFERENCES}

1. Collins, A. N., Sheldrake, G. N., Crosby, J., Chirality in Industry: The commercial Manufacture and Applications of Optically Active Compounds. John Wiley \& Sons: Chichester, 1992.

2. Shimizu, H.; Nagasaki, I.; Matsumura, K.; Sayo, N.; Saito, T., Acc. Chem. Res. 2007, 40, 1385-1393. 
3. Blaser, H.-U.; Pugin, B.; Spindler, F., Asymmetric Hydrogenation. In Organometallics as Catalysts in the Fine Chemical Industry, Beller, M.; Blaser, H. U., Eds. 2012; Vol. 42, pp 65102.

4. $\quad$ Magano, J.; Dunetz, J. R., Org. Process Res. Dev. 2012, 16, 1156-1184.

5. $\quad$ Noyori, R.; Hashiguchi, S., Acc. Chem. Res. 1997, 30, 97-102.

6. $\quad$ Noyori, R.; Ohkuma, T., Angew. Chem. Engl. 2001, 40, 40-73.

7. Noyori, R., Angew. Chem., Int. Ed. Eng. 2002, 41, 2008-2022.

8. $\quad$ Knowles, W. S.; Noyori, R., Acc. Chem. Res. 2007, 40, 1238-1239.

9. Ikariya, T.; Blacker, A. J., Acc. Chem. Res. 2007, 40, 1300-1308.

10. Wang, C.; Wu, X. F.; Xiao, J. L., Chem. Asian J. 2008, 3, 1750-1770.

11. Ohkuma, T.; Ooka, H.; Hashiguchi, S.; Ikariya, T.; Noyori, R., J. Am. Chem. Soc. 1995, $117,2675-2676$.

12. $\quad$ Doucet, H.; Ohkuma, T.; Murata, K.; Yokozawa, T.; Kozawa, M.; Katayama, E.;

England, A. F.; Ikariya, T.; Noyori, R., Angew. Chem. Engl. 1998, 37, 1703-1707.

13. Ohkuma, T.; Koizumi, M.; Doucet, H.; Pham, T.; Kozawa, M.; Murata, K.; Katayama, E.; Yokozawa, T.; Ikariya, T.; Noyori, R., J. Am. Chem. Soc. 1998, 120, 13529-13530.

14. Matsumura, K.; Arai, N.; Hori, K.; Saito, T.; Sayo, N.; Ohkuma, T., J. Am. Chem. Soc. 2011, 133, 10696-10699.

15. Jiang, Q.; Jiang, Y.; Xiao, D.; Cao, P.; Zhang, X., Angew. Chem., Int. Ed. Eng. 1998, 37, $1100-1103$.

16. Zhang, Z. G.; Qian, H.; Longmire, J.; Zhang, X. M., J. Org. Chem. 2000, 65, 6223-6226.

17. Burk, M. J.; Kalberg, C. S.; Pizzano, A., J. Am. Chem. Soc. 1998, 120, 4345-4353.

18. Murata, K.; Ikariya, T., J. Org. Chem. 1999, 64, 2186-2187.

19. Mao, J. M.; Baker, D. C., Org. Lett. 1999, 1, 841-843.

20. Dahlenburg, L.; Goetz, R., Eur. J. Inorg. Chem. 2004, 888-905.

21. Dahlenburg, L.; Goetz, R., Inorg. Chim. Acta 2004, 357, 2875-2880.

22. Dahlenburg, L.; Menzel, R.; Heinemann, F. W., Eur. J. Inorg. Chem. 2007, 4364-4374.

23. Ferrand, A.; Bruno, M.; Tommasino, M. L.; Lemaire, M., Tetrahedron: Asymmetry 2002, $13,1379-1384$.

24. Xie, J.-B.; Xie, J.-H.; Liu, X.-Y.; Zhang, Q.-Q.; Zhou, Q.-L., Chem. Asian J. 2011, 6, 899-908.

25. Irrgang, T.; Friedrich, D.; Kempe, R., Angew. Chem. Engl. 2011, 50, 2183-2186.

26. Xie, J.-H.; Liu, X.-Y.; Xie, J.-B.; Wang, L.-X.; Zhou, Q.-L., Angew. Chem. Engl. 2011, 50, 7329-7332.

27. Casey, C. P.; Guan, H. R., J. Am. Chem. Soc. 2007, 129, 5816-5817.

28. Casey, C. P.; Guan, H., J. Am. Chem. Soc. 2009, 131, 2499-2507.

29. Sui-Seng, C.; Freutel, F.; Lough, A. J.; Morris, R. H., Angew. Chem. Engl. 2008, 47, 940943.

30. Jothimony, K.; Vancheesan, S.; Kuriacose, J. C., J. Mol. Catal. 1985, 32, 11-16.

31. Jothimony, K.; Vancheesan, S., J. Mol. Catal. 1989, 52, 301-304.

32. Enthaler, S.; Hagemann, B.; Erre, G.; Junge, K.; Beller, M., Chem. Asian J. 2006, 1, 598604.

33. Enthaler, S.; Erre, G.; Tse, M. K.; Junge, K.; Beller, M., Tetrahedron Lett. 2006, 47, 8095-8099.

34. Furuta, A.; Nishiyama, H., Tetrahedron Lett. 2008, 49, 110-113.

35. Zuo, W.; Lough, A. J.; Li, Y. F.; Morris, R. H., Science 2013, 342, 1080-1083. 
36. Lagaditis, P. O.; Sues, P. E.; Sonnenberg, J. F.; Wan, K. Y.; Lough, A. J.; Morris, R. H., J. Am. Chem. Soc. 2014, 136, 1367-1380.

37. Blaser, H.-U.; Indolese, A.; Naud, F.; Nettekoven, U.; Schnyder, A., Adv. Synth. Catal. 2004, 346, 1583-1598.

38. Bianchini, C.; Gonsalvi, L.; Peruzzini, M., Iridium-catalyzed C=O hydrogenation. In Iridium Complexes in Organic Synthesis, Oro, L. A.; Claver, C., Eds. Wiley-VCH: Weinheim, 2009; pp 55-106.

39. Malacea, R.; Poli, R.; Manoury, E., Coord. Chem. Rev. 2010, 254, 729-752.

40. Yan, P.-C.; Zhu, G.-L.; Xie, J.-H.; Zhang, X.-D.; Zhou, Q.-L.; Li, Y.-Q.; Shen, W.-H.; Che, D.-Q., Org. Process Res. Dev. 2013, 17, 307-312.

41. Comas-Vives, A.; Ujaque, G.; Lledos, A., Adv. Inorg. Chem. 2010, 62, 231-260.

42. Eisenstein, O.; Crabtree, R. H., New J. Chem. 2013, 37, 21-27.

43. Abdur-Rashid, K.; Clapham, S. E.; Hadzovic, A.; Harvey, J. N.; Lough, A. J.; Morris, R. H., J. Am. Chem. Soc. 2002, 124, 15104-15118.

44. Sandoval, C. A.; Ohkuma, T.; Muniz, K.; Noyori, R., J. Am. Chem. Soc. 2003, 125, 13490-13503.

45. Alonso, D. A.; Brandt, P.; Nordin, S. J. M.; Andersson, P. G., J. Am. Chem. Soc. 1999, 121, 9580-9588.

46. Petra, D. G. I.; Reek, J. N. H.; Handgraaf, J. W.; Meijer, E. J.; Dierkes, P.; Kamer, P. C. J.; Brussee, J.; Schoemaker, H. E.; van Leeuwen, P., Chem. Eur. J. 2000, 6, 2818-2829.

47. Yamakawa, M.; Yamada, I.; Noyori, R., Angew. Chem. Engl. 2001, 40, 2818-2821.

48. French, S. A.; Di Tommaso, D.; Zanotti-Gerosa, A.; Hancock, F.; Catlow, C. R. A., Chem. Commun. 2007, 2381-2383.

49. Di Tommaso, D.; French, S. A.; Catlow, C. R. A., Theochem-J. Mol. Struct. 2007, 812, 39-49.

50. Handgraaf, J. W.; Meijer, E. J., J. Am. Chem. Soc. 2007, 129, 3099-3103.

51. Leyssens, T.; Peeters, D.; Harvey, J. N., Organometallics 2008, 27, 1514-1523.

52. Di Tommaso, D.; French, S. A.; Zanotti-Gerosa, A.; Hancock, F.; Palin, E. J.; Catlow, C. R. A., Inorg. Chem. 2008, 47, 2674-2687.

53. Chen, Y.; Tang, Y.; Lei, M., Dalton Trans. 2009, 2359-2364.

54. Lei, M.; Zhang, W. C.; Chen, Y.; Tang, Y. H., Organometallics 2010, 29, 543-548.

55. Chen, H.-Y. T.; Di Tommaso, D.; Hogarth, G.; Catlow, C. R. A., Dalton Trans. 2011, 40, 402-412.

56. Chen, H.-Y. T.; Di Tommaso, D.; Hogarth, G.; Catlow, C. R. A., Catal. Lett. 2011, 141, 1761-1766.

57. Chen, H.-Y. T.; Di Tommaso, D.; Hogarth, G.; Catlow, C. R. A., Dalton Trans. 2012, 41, 1867-1877.

58. Hasanayn, F.; Morris, R. H., Inorg. Chem. 2012, 51, 10808-10818.

59. Zhang, X.; Guo, X.; Chen, Y.; Tang, Y.; Lei, M.; Fang, W., Phys. Chem. Chem. Phys.

2012, 14, 6003-6012.

60. Zhang, X.; Guo, X. J.; Chen, Y.; Tang, Y. H.; Lei, M.; Fang, W. H., Phys. Chem. Chem. Phys. 2012, 14, 6003-6012.

61. $\quad$ Prokopchuk, D. E.; Morris, R. H., Organometallics 2012, 31, 7375-7385.

62. Pavlova, A.; Meijer, E. J., Chemphyschem 2012, 13, 3492-3496.

63. Faza, O. N.; Lopez, C. S.; Fernandez, I., J. Org. Chem. 2013, 78, 5669-5676.

64. Feng, R.; Xiao, A.; Zhang, X.; Tang, Y.; Lei, M., Dalton Trans. 2013, 42, 2130-2145. 
65. Nieto Faza, O.; Fernandez, I.; Silva Lopez, C., Chem. Commun. 2013, 49, 4277-4279.

66. Dub, P. A.; Ikariya, T., J. Am. Chem. Soc. 2013, 135, 2604-2619.

67. Yamakawa, M.; Ito, H.; Noyori, R., J. Am. Chem. Soc. 2000, 122, 1466-1478.

68. Dub, P. A.; Henson, N. J.; Martin, R. L.; Gordon, J. C., J. Am. Chem. Soc. 2014, 136, 3505-3521.

69. Malacea, R.; Manoury, E.; Routaboul, L.; Daran, J.-C.; Poli, R.; Dunne, J. P.; Withwood, A. C.; Godard, C.; Duckett, S. B., Eur. J. Inorg. Chem. 2006, 1803-1816.

70. Le Roux, E.; Malacea, R.; Manoury, E.; Poli, R.; Gonsalvi, L.; Peruzzini, M., Adv. Synth. Catal. 2007, 349, 309-313.

71. Kvintovics, P.; Bakos, J.; Heil, B., J. Mol. Catal. 1985, 32, 111-114.

72. Spogliarich, R.; Kaspar, J.; Graziani, M., J. Organomet. Chem. 1986, 306, 407-412.

73. Zassinovich, G.; Mestroni, G., J. Mol. Catal. 1987, 42, 81-90.

74. Zassinovich, G.; Bettella, R.; Mestroni, G.; Bresciani-Pahor, N.; Geremia, S.; Randaccio, L., J. Organomet. Chem. 1989, 370, 187-202.

75. Debono, N.; Besson, M.; Pinel, C.; Djakovitch, L., Tetrahedron Lett. 2004, 45, $2235-$ 2238.

76. Ajjou, A. N.; Pinet, J. L., J. Mol. Catal. A 2004, 214, 203-206.

77. $\quad$ Lundgren, R. J.; Stradiotto, M., Chem. Eur. J. 2008, 14, 10388-10395.

78. Paredes, P.; Diez, J.; Gamasa, M. P., Organometallics 2008, 27, 2597-2607.

79. Binobaid, A.; Iglesias, M.; Beetstra, D.; Dervisi, A.; Fallis, I.; Cavell, K. J., Eur. J. Inorg. Chem. 2010, 5426-5431.

80. Jimenez, M. V.; Fernandez-Tornos, J.; Perez-Torrente, J. J.; Modrego, F. J.; Winterle, S.; Cunchillos, C.; Lahoz, F. J.; Oro, L. A., Organometallics 2011, 30, 5493-5508.

81. Kozinets, E. M.; Belkova, N. V.; Shubina, E. S.; Poli, R.; Manoury, E., Russ. Chem. Bull. 2013, 750-756.

82. Tollner, K.; PopovitzBiro, R.; Lahav, M.; Milstein, D., Science 1997, 278, 2100-2102.

83. Iron, M. A.; Sundermann, A.; Martin, J. M. L., J. Am. Chem. Soc. 2003, 125, 1143011441.

84. Kozinets, E. M.; Fekete, M.; Filippov, O. A.; Belkova, N. V.; Shubina, E. S.; Poli, R.; Duckett, S. B.; Manoury, E., Dalton Trans. 2013, 42, 11720-11730.

85. Boyd, S. L.; Boyd, R. J., J. Chem. Theory Comput. 2007, 3, 54-61.

86. Abdur-Rashid, K.; Gusev, D. G.; Landau, S. E.; Lough, A. J.; Morris, R. H., J. Am.

Chem. Soc. 1998, 120, 11826-11827.

87. Landau, S. E.; Groh, K. E.; Lough, A. J.; Morris, R. H., Inorg. Chem. 2002, 41, 29953007.

88. Guilera, G.; McGrady, G. S.; Steed, J. W.; Jones, A. L., Organometallics 2006, 25, $122-$ 127.

89. Grey, R. A.; Pez, G. P.; Wallo, A.; Corsi, J., Chem. Commun. 1980, 783-784.

90. Grey, R. A.; Pez, G. P.; Wallo, A., J. Am. Chem. Soc. 1981, 103, 7536-7542.

91. Pez, G. P.; Grey, R. A.; Corsi, J., J. Am. Chem. Soc. 1981, 103, 7528-7535.

92. Grey, R. A.; Pez, G. P.; Wallo, A.; Corsi, J., Ann. New York Acad. Sci. 1983, 415, $235-$

243.

93. Wilczynski, R.; Fordyce, W. A.; Halpern, J., J. Am. Chem. Soc. 1983, 105, 2066-2068.

94. Fordyce, W. A.; Wilczynski, R.; Halpern, J., J. Organomet. Chem. 1985, 296, 115-125.

95. Linn, D. E.; Halpern, J., J. Am. Chem. Soc. 1987, 109, 2969-2974. 
96. Gusev, G. D.; Bakhmutov, V. I.; Vymenits, A. B.; Vol'pin, M. E., Metalloorg. Khim. 1990, 3, 1432-1434.

97. Gusev, D. G.; Vymenits, A. B.; Bakhmutov, V. I., Inorg. Chim. Acta 1991, 179, 195-201.

98. Toner, A. J.; Donnadieu, B.; Sabo-Etienne, S.; Chaudret, B.; Sava, X.; Mathey, F.; Floch, P. L., Inorg. Chem. 2001, 40, 3034-3038.

99. Chan, A. S. C.; Shieh, H. S., Chem. Commun. 1985, 1379-1380.

100. Plois, M.; Wolf, R.; Hujo, W.; Grimme, S., Eur. J. Inorg. Chem. 2013, 3039-3048.

101. Bielinski, E. A.; Forster, M.; Zhang, Y.; Bernskoetter, W. H.; Hazari, N.; Holthausen, M. C., ACS Catal. 2015, 5, 2404-2415.

102. Hartmann, R.; Chen, P., Angew. Chem. Engl. 2001, 40, 3581-3585.

103. Xie, J. H.; Liu, S.; Huo, X. H.; Cheng, X.; Duan, H. F.; Fan, B. M.; Wang, L. X.; Zhou, Q. L., J. Org. Chem. 2005, 70, 2967-2973.

104. Routaboul, L.; Vincendeau, S.; Daran, J.-C.; Manoury, E., Tetrahedron: Asymmetry 2005, 16, 2685-2690.

105. Zhao, Y.; Truhlar, D. G., Theor. Chem. Acc. 2008, 120, 215-241.

106. Frisch, M. J.; Trucks, G. W.; Schlegel, H. B.; Scuseria, G. E.; Robb, M. A.; Cheeseman, J. R.; Scalmani, G.; Barone, V.; Mennucci, B.; Petersson, G. A.; Nakatsuji, H.; Caricato, M.; Li, X.; Hratchian, H. P.; Izmaylov, A. F.; Bloino, J.; Zheng, G.; Sonnenberg, J. L.; Hada, M.; Ehara, M.; Toyota, K.; Fukuda, R.; Hasegawa, J.; Ishida, M.; Nakajima, T.; Honda, Y.; Kitao, O.;

Nakai, H.; Vreven, T.; Montgomery, J., J. A.; Peralta, J. E.; Ogliaro, F.; Bearpark, M.; Heyd, J. J.; Brothers, E.; Kudin, K. N.; Staroverov, V. N.; Kobayashi, R.; Normand, J.; Raghavachari, K.; Rendell, A.; Burant, J. C.; Iyengar, S. S.; Tomasi, J.; Cossi, M.; Rega, N.; Millam, N. J.; Klene, M.; Knox, J. E.; Cross, J. B.; Bakken, V.; Adamo, C.; Jaramillo, J.; Gomperts, R.; Stratmann, R. E.; Yazyev, O.; Austin, A. J.; Cammi, R.; Pomelli, C.; Ochterski, J. W.; Martin, R. L.; Morokuma, K.; Zakrzewski, V. G.; Voth, G. A.; Salvador, P.; Dannenberg, J. J.; Dapprich, S.; Daniels, A. D.; Farkas, Ö.; Foresman, J. B.; Ortiz, J. V.; Cioslowski, J.; Fox, D. J., Gaussian 09, Revision D.01. Gaussian, Inc.: Wallingford CT, 2009.

107. Andrae, D.; Haussermann, U.; Dolg, M.; Stoll, H.; Preuss, H., Theor. Chim. Acta 1990, 77, 123-141.

108. Ehlers, A. W.; Boehme, M.; Dapprich, S.; Gobbi, A.; Hoellwarth, A.; Jonas, V.; Koehler, K. F.; Stegmann, R.; Veldkamp, A.; Frenking, G., Chem. Phys. Lett. 1993, 208, 111-114.

109. Francl, M. M.; Pietro, W. J.; Hehre, W. J.; Binkley, J. S.; Gordon, M. S.; Defrees, D. J.; Pople, J. A., J. Chem. Phys. 1982, 77, 3654-3665.

110. Marenich, A. V.; Cramer, C. J.; Truhlar, D. G., J. Phys. Chem. B 2009, 113, 6378-6396.

111. Bryantsev, V. S.; Diallo, M. S.; Goddard, W. A., III, J. Phys. Chem. B 2008, 112, 97099719.

Table of Contents Graphic 


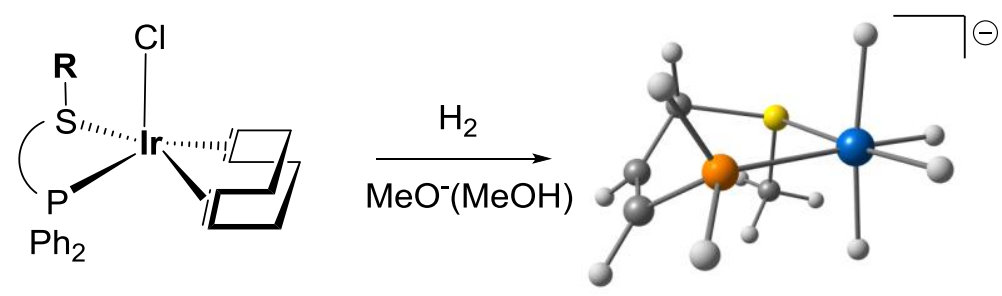

\section{Synopsis}

Activation of $[\operatorname{IrCl}(\mathrm{COD})(\mathrm{PS})],[\operatorname{IrCl}(\mathrm{COD})]_{2} / \mathrm{PS}$ or $[\operatorname{Ir}(\mathrm{OMe})(\mathrm{COD})]_{2} / \mathrm{PS}(\mathrm{PS}=$ ferrocenyl phosphine thioether) under $\mathrm{H}_{2}$ requires the presence of a strong base such as $\mathrm{MeONa}$ in order to yield an efficient ketone hydrogenation catalyst. A computational investigation using $\left[\mathrm{MeO}(\mathrm{MeOH})_{\mathrm{n}}\right]^{-}$as a model base for deprotonation yields anionic $\left[\mathrm{IrH}_{4}(\mathrm{PS})\right]^{-}$as the lowest energy species. A catalytic cycle starting from the $\left[\mathrm{Na}^{+}(\mathrm{MeOH})_{3} \cdots \mathrm{Ir}^{-} \mathrm{H}_{4}(\mathrm{PS})\right]$ contact ion pair yields an energy span in agreement with the experimentally observed efficiency. 